\title{
Diagnostic utility of snail in metaplastic breast carcinoma
}

\author{
Aziza Nassar ${ }^{*}$, Nicole Sookhan ${ }^{2}$, Marta Santisteban ${ }^{3}$, Sandra C Bryant ${ }^{4}$, Judy C Boughey ${ }^{5}$, Tamar Giorgadze ${ }^{6}$, \\ Amy Degnim ${ }^{5}$
}

\begin{abstract}
Metaplastic breast carcinoma (MBC) is a rare subtype of breast cancer characterized by coexistence of carcinomatous and sarcomatous components. Snail is a nuclear transcription factor incriminated in the transition of epithelial to mesenchymal differentiation of breast cancer. Aberrant Snail expression results in lost expression of the cell adhesion molecule E-cadherin, an event associated with changes in epithelial architecture and invasive growth. We aimed to identify the utility of Snail, and of traditional immunohistochemical markers, in accurate MBC classification and to evaluate clinicopathologic characteristics and outcome.

We retrospectively reviewed 34 MBC cases from January 1997 to September 2007. The control group contained 26 spindle cell lesions. Immunohistochemistry used Snail, p63, epidermal growth factor receptor (EGFR), OSCAR, and wide spectrum cytokeratin (WS-KER). Negative was a score less than $1 \%$. We found that Snail and EGFR are sensitive (100\%) markers with low specificity (3.8\% and 19.2\%) for detecting MBC. p63 and WS-KER are specific (100\%), with moderate sensitivity (67.6\% and $76.5 \%)$; OSCAR is sensitive (85.3\%) and specific (92.3\%). A combination of any 2 of the p63, OSCAR, and WS-KER markers increased sensitivity and specificity. MBCs tended to be highgrade (77\%), triple negative (negative for estrogen receptor, progesterone receptor, and HER2) [27/33; 81.8\%], and carcinomas with low incidence of axillary lymph node involvement (15\%), and decreased disease-free [71\% (95\%Cl: $54 \%, 94 \%)$ at 3 yrs.) and overall survival. A combination of p63, OSCAR and WS-KER are useful in its work-up. On the other hand, Snail is neither a diagnostic nor a prognostic marker for MBC.
\end{abstract}

\section{Background}

Metaplastic breast carcinoma $(\mathrm{MBC})$ is a rare subtype of breast cancer characterized by carcinomatous and sarcomatous components. Clinically, MBCs have a large size at diagnosis, lack expression of hormone receptors, and have a lower incidence of regional lymph nodes and a higher rate of systemic disease than ductal carcinomas of the breast [1]. Thus, the likelihood for recurrence of $\mathrm{MBC}$ is high, translating into a poor outcome. MBCs comprise less than $5 \%$ of mammary adenocarcinomas, and they generally present as rapidly growing, palpable tumors with circumscribed contours and a high-density mass with associated architectural distortion radiographically [1-3].

Customarily, MBCs are divided into 2 main categories: squamous and heterologous or pseudosarcomatous

\footnotetext{
* Correspondence: nassar.aziza@mayo.edu

'Department of Laboratory Medicine and Pathology, Mayo Clinic, Rochester, MN, USA

Full list of author information is available at the end of the article
}

metaplasia. They have lower frequency of axillary lymph node metastases than non-metaplastic high-grade carcinomas [1]. Prognosis of $\mathrm{MBC}$ is determined by stage at diagnosis. It is unclear whether the histologic type of metaplasia has a significant effect on prognosis.

Transformation of the carcinomatous component into the sarcomatous component through epithelial-tomesenchymal transition could explain the origin of the MBC [4]. This transition is a physiologic program used in embryogenesis and also activated during cancer invasion, progression and metastasis, in which cancer cells lose their adherent and polarity features and change into a mesenchymal phenotype with a more elongated cellular shape for increasing motility.

Association of breast cancer and epithelial-tomesenchymal transition has been described in the medical literature [5], and now its role in the generation of the breast cancer stem cell phenotype has acquired a heightened interest [6,7]. Indeed, the tumoral microenvironment enhances extracellular stimuli such as
C Biomed Central

C 2010 Nassar et al; licensee BioMed Central Ltd. This is an Open Access article distributed under the terms of the Creative Commons Attribution License (http://creativecommons.org/licenses/by/2.0), which permits unrestricted use, distribution, and reproduction in any medium, provided the original work is properly cited. 
increased matrix metalloproteinases production, to facilitate migration and invasion.

Epithelial-to-mesenchymal transition has been related to upregulation of the transcriptional repressor Snail [8], which is associated with loss of the epithelial adhesion molecule E-cadherin $[9,10]$, and predicts a worse outcome in progression-free survival for women with breast cancer [8]. High Snail expression in breast cancers found with microarray analysis was significantly associated with a poor relapse-free survival in nonmetaplastic breast carcinomas [11-13]. Moreover, Snail expression predicts disease-free survival independently of lymph node status and tumor size [8]. A negative correlation was shown between Snail and estrogen receptor expression driven by the MTA3 (metastasis-associated protein) pathway [14].

Accurate diagnosis and differentiation of $\mathrm{MBC}$ from other spindle cell lesions of the breast can be challenging, especially in core needle biopsies [15]. In the present study, our primary aim was to study and compare Snail with other known traditional immunomarkers used in identifying $\mathrm{MBC}$ and to evaluate its correlation with tumor characteristics and outcome. Our secondary aim was to review our experience in the multidisciplinary management of MBC cases over a 10-year period, examining clinicopathologic features, treatment, and outcomes.

\section{Materials and methods}

\section{Tissue specimens}

The study was approved by the institutional review boards of our respective Institution. We conducted a retrospective review of 34 patients who received a diagnosis of $\mathrm{MBC}$ at a tertiary referral center from February 1997 to August 2007. Patient age, tumor size and grade, nodal status, hormone receptor status, initial treatment, recurrence, and follow up information were reviewed (Table 1).

The cases of MBC contained 20 cases of spindle cell type, 5 mixed spindle and squamous cell type, 4 squamous cell type, 3 matrix producing type, and 2 low-grade adenosquamous carcinoma. All patients with MBC were females with an average age of 62 yrs. (range: 32 - 90 yrs.). All tumors were characterized histologically according to Wartgotz's criteria [16-19]. The control group consisted of 26 spindle cell lesions: 14 phyllodes tumors, 8 pseudoangiomatous stromal hyperplasias (PASH), and 4 myofibroblastomas. The majority of the patients in the control group were females (23) with only few males (3) who presented with myofibroblastoma. The average age in the control group is 53 yrs. (range: $17-86$ yrs.).

\section{Immunohistochemistry}

The following immunohistochemical stains were performed: Snail, epidermal growth factor receptor (EGFR),
Table 1 Clinicopathologic factors of $\mathbf{3 4}$ patients with metaplastic breast carcinoma

\begin{tabular}{|c|c|c|}
\hline Age (years), mean (range) & $61.8(32-90)$ & \\
\hline \multicolumn{3}{|l|}{ Histologic grade, n (\%) } \\
\hline Low grade & $6(17.6 \%)$ & \\
\hline Intermediate grade & $2(5.9 \%)$ & \\
\hline High grade & $26(76.5 \%)$ & \\
\hline \multicolumn{3}{|l|}{ Histologic subtypes } \\
\hline Spindle cell & $20(58.8 \%)$ & \\
\hline Mixed squamous and spindle cell & $5(14.7 \%)$ & \\
\hline Squamous & $4(11.8 \%)$ & \\
\hline Matrix producing & $3(8.8 \%)$ & \\
\hline Adenosquamous & $2(5.9 \%)$ & \\
\hline $\begin{array}{l}\text { Tumor diameter }(\mathbf{c m}), \text { median } \\
\text { (range) }\end{array}$ & $3.0(0.8-24)$ & \\
\hline \multirow[t]{4}{*}{ Tumor size } & $\mathrm{T} 1$ & $\begin{array}{l}10 \\
(29.4 \%)\end{array}$ \\
\hline & $\mathrm{T} 2$ & $\begin{array}{l}14 \\
(41.2 \%)\end{array}$ \\
\hline & T3 & $6(17.6 \%)$ \\
\hline & T4 & $4(11.8 \%)$ \\
\hline
\end{tabular}

\begin{tabular}{ll}
\hline Receptor Status \\
ER positive & $4(12.1 \%)$ \\
PR positive & $3(9.1 \%)$ \\
Her2 positive & $2(5.9 \%)$ \\
\hline $\begin{array}{l}\text { Lymph node status } \\
\text { Positive }\end{array}$ & $5(14.7 \%)$ \\
Negative & $29(85.3 \%)$ \\
\hline Surgery & \\
Mastectomy & $21(61.8 \%)$ \\
BCT & $13(38.2 \%)$ \\
\hline Adduvant treatment
\end{tabular}

\begin{tabular}{lll}
\hline $\begin{array}{l}\text { Adjuvant treatment } \\
\text { Chemotherapy } \\
\text { Radiation }\end{array}$ & $14(41.2 \%)$ & \\
\hline Recurrence & $17(50.0 \%)$ & \\
& Local & $3(8.8 \%)$ \\
& Distant & $4(11.8 \%)$
\end{tabular}

Overall survival, median $(95 \% \mathrm{Cl})$

$\begin{array}{ll}1 \text { year } & 82.8 \%(70.1 \%, \\ & 97.8 \%) \\ 3 \text { years } & 58.4 \%(42.0 \%, \\ & 81.4 \%)\end{array}$

\begin{tabular}{|c|c|}
\hline $\begin{array}{l}\text { Disease-free } \\
\left(\left.\right|^{*}\right)\end{array}$ & \\
\hline 1 year & $\begin{array}{l}78.5 \% \text { (64.4\%, } \\
95.5 \%)\end{array}$ \\
\hline 3 years & $\begin{array}{l}71.3 \%(54.4 \%, \\
93.6 \%)\end{array}$ \\
\hline
\end{tabular}

${ }^{*} \mathrm{Cl}=$ Confidence Interval

OSCAR (a broad spectrum cytokeratin), wide spectrum cytokeratin (WS-KER) and p63, using these antibodies and positive controls listed in Table 2. Negative controls were run simultaneously and had primary antibody replaced with buffer. EGFR immunostain was performed 
Table 2 Immunohistochemical stains used, including their clones, dilutions, source and controls

\begin{tabular}{cccccc}
\hline Antibody & Monoclonal/polyclonal & Clone & Dilution & Source & Positive Control \\
\hline SNAIL & $M$ & AbcamAb17732 & $1: 500$ & DAKOCarpinteria, CA & Breast cancer \\
\hline EGFR & $M$ & DAKO kit & prediluted & DAKOCarpinteria, CA & Colon cancer \\
\hline OSCAR & $M$ & OSCAR & $1: 200$ & DAKOCarpinteria, CA & Tonsil \\
\hline WS-KER & P & Cytokeratin Wide Spectrum (WSS) & 1:1600 & DAKOCarpinteria, CA & Breastcancer \\
\hline P63 & $M$ & PIN2 cocktail & prediluted & DAKOCarpinteria, CA & Prostate cancer \\
\hline
\end{tabular}

EGFR = epidermal growth factor receptor; WS-KER = wide spectrum keratin

with kits approved by the Food and Drug Administration (EGFR PharmDX;, Dako North America, Inc, Carpinteria, California) used in accordance with manufacturer instructions for antigen retrieval and immunostaining method. Antigen retrieval for all other antibodies was conducted in citrate buffer $(\mathrm{pH}, 6.0)$ under a pressure of 15 pounds per square inch for 3 minutes. The EnVision+ Dual Link Kit (Dako) was used for all immunostaining, with an automated slide stainer and with diaminobenzidine as chromogen and hematoxylin as counterstain.

Immunohistochemical staining was performed as follows. Formalin-fixed, paraffin-embedded samples, cut at $5 \mu \mathrm{m}$ onto charged slides and baked at $60^{\circ} \mathrm{C}$ for $40 \mathrm{~min}$ utes prior before staining, were deparaffinized with 3 changes of xylene and rehydrated in a series of graded alcohols (100\% ethanol, 95\% ethanol, and 70\% ethanol), then rinsed well in running distilled water. Slides were placed in a preheated citrate retrieval buffer $(\mathrm{pH}, 6.0)$ for 30 minutes, in a water steamer, cooled in the buffer for 5 minutes, and rinsed for 5 minutes in running distilled water.

Slides were placed on an automated slide stainer (AS100 Autostainer Plus; DAKO, Carpinteria, CA) for the following procedure (at room temperature). Sections were incubated with $3 \%$ hydrogen peroxide in ethanol for 5 minutes to inactivate endogenous peroxidases. They then were incubated in primary antibody for 30 minutes, rinsed with TBST wash buffer (S3006, TrisBuffered Saline with Tween 20; DAKO) and incubated for 15 minutes with a peroxidase-labeled polymer conjugated to the secondary antibody. After a rinse with TBST wash buffer, sections were incubated in 3,3'-diaminobenzidine (K3468, DAB+ Substrate Chromogen; Dako) for 5 minutes, counterstained with modified Schmidt's hematoxylin for 5 minutes, followed by a 3- minute tap water rinse to set counterstain, dehydrated through graded alcohols (70\% ethanol, $95 \%$ ethanol, and $100 \%$ ethanol), cleared in 3 changes of xylene, and mounted with permanent mounting media.

Antibody staining was membranous for EGFR, nuclear for PIN2 cocktail (p63) and Snail, and cytoplasmic for OSCAR and WS-KER. For all markers, scoring was performed using a score of less than $1 \%$ as negative. Several different microscopic fields (at least 10) per low and medium-power fields are examined for staining assessment.

\section{Statistical Analysis}

Results were analyzed statistically with the sensitivity, specificity, and positive and negative predictive values for the different antibodies studied. Disease-free survival and overall survival were analyzed by the Kaplan-Meier survival curves. Associations of overall survival and surgery type, chemotherapy and radiotherapy were performed using the log rank test. Associations of tumor characteristics and snail percentage were assessed using Wilcoxon rank sum tests, while the association between snail percentage and age or tumor size was assessed using linear regression. In all cases, significance was defined as p-value $<0.05$.

\section{Results}

\section{Clinicopathologic characteristics (Table 2)}

A total of 34 patients were identified (mean age, $61.8 \mathrm{y}$ [range, 32-90 y]). Of them, 29 patients (85\%) presented with a palpable lump and 5 (15\%) had an abnormal mammogram; 27 (81.8\%) patients had triple-negative hormonal receptor status (negative for estrogen receptor, progesterone receptor, and HER2). Approximately $76 \%(26 / 34)$ of patients have high-grade tumors. The distribution of tumor sizes was 10 patients with T1, and 14, 6 and 4 patients with T2, T3 and T4 tumors respectively.

All patients had sentinel lymph node biopsy (100\%), and only four patients had axillary lymph node (ALN) dissection (30.8\%; 4/13). Five (15\%) patients were lymph node positive. Those with positive ALNs have larger (pT2 or above) tumor size $(\mathrm{p}=0.02)$. Twenty-one $(62 \%)$ patients underwent mastectomy and 13 (38\%) underwent breast conservation therapy (BCT). Fourteen patients (41\%) received chemotherapy and seventeen (50\%) patients received radiotherapy, 13 of whom received breast radiation as part of BCT. Neither chemotherapy nor radiotherapy increased survival of these patients ( $\mathrm{p}=0.87$ and 0.13 , respectively). Two patients were lost to follow up, with a median follow-up time of 21 months for the remaining 32. Three patients had local recurrences which occurred within 6 months, and 
4 had distant metastases to lung and bone. Five patients died within the first year of diagnosis, 9 additional patients died by 5 years, and 2 more died by 10 years. The Kaplan-Meier estimated disease-free survival and 95\% confidence interval (CI) was found to be $78.5 \%$ $(64.4 \%, 95.5 \%)$ at 1 year and $71.3 \%(54.4 \%, 93.6 \%)$ at 3 years. The Kaplan-Meier estimated overall survival and 95\% CI was found to be $82.8 \%(70.1 \%, 97.8 \%)$ at 1 year and $58.4 \%(42.0 \%, 81.4 \%)$ at 3 years as shown in Figure 1. Patients treated with BCT had statistically better overall survival than those with mastectomy ( $\mathrm{p}=0.029$ by $\log$ rank test) as shown in Figure 2. This is partly attributed to lower tumor size (pT) in patients who underwent $\mathrm{BCT}$ (median tumor size is $1.5 \mathrm{~cm}$ ) than those who had mastectomy (median tumor side is $4.8 \mathrm{~cm}$ ) [p $<0.0001$ ]. Although not statistically significant $(\mathrm{p}=0.828)$, mastectomy patients more frequently had high grade tumors (81\%) compared with BCT patients (69\%). Finally, survival of these patients was not associated with age, tumor size, grade, ALN status, hormone receptor and HER2 status, and type of treatment (all $\mathrm{p}>0.06$ ).

\section{Immunohistochemical analysis}

The results of the immunohistochemical analyses are as shown in Tables $3 \& 4$ and Figures $3 \& 4$. Snail was a sensitive (100\%) marker for identifying MBC. However it was not a specific (3.8\%) marker, as it was seen in other spindle cell lesions, including myofibroblastoma $(4 / 4 ; 100 \%)$; phyllodes tumor $(14 / 14 ; 100 \%)$ and PASH (7/8; 87.5\%).

EGFR was also a sensitive marker (100\%) but had a low specificity $(19.2 \%)$, whereas p63 was a very specific marker $(100 \%)$ for MBC but had a lower sensitivity (67.6\%) compared to both EGFR and Snail. OSCAR keratin and WS-KER were both comparable in their sensitivity ( $85.3 \%$ and $76.5 \%$ respectively) and specificity (92.3\% and $100 \%$ respectively) for detecting MBC. When several of those immunomarkers (OSCAR, p63 and WS-KER) were combined, both the sensitivity (82.4 to $88.2 \%)$ and specificity (92.3 to $100 \%$ ) were increased, with the combination of p63 and WS-KER being the best two antibodies for detecting MBC in terms of high specificity (100\%).

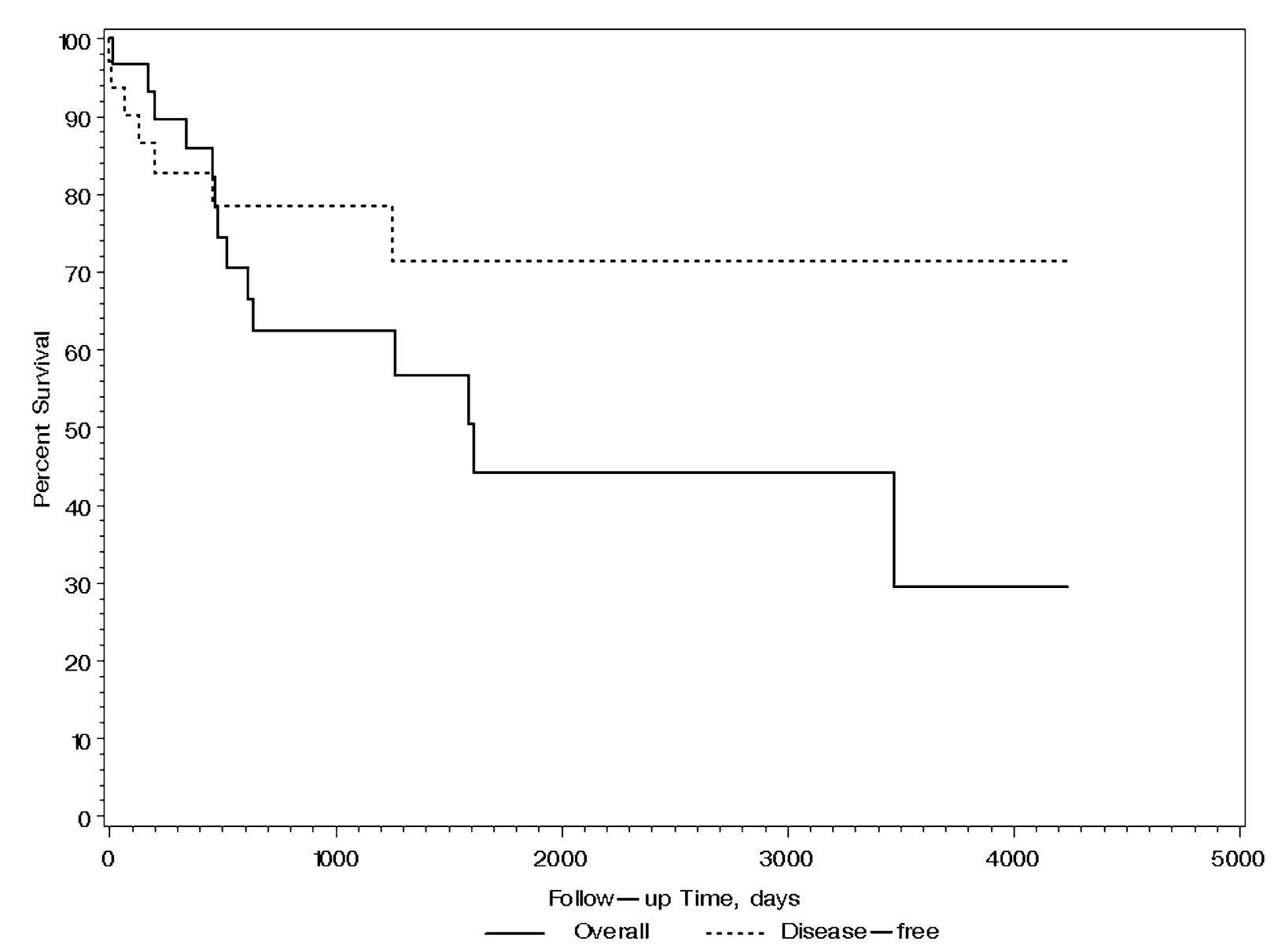

Figure 1 Overall and disease-free survival of patients with MBC 


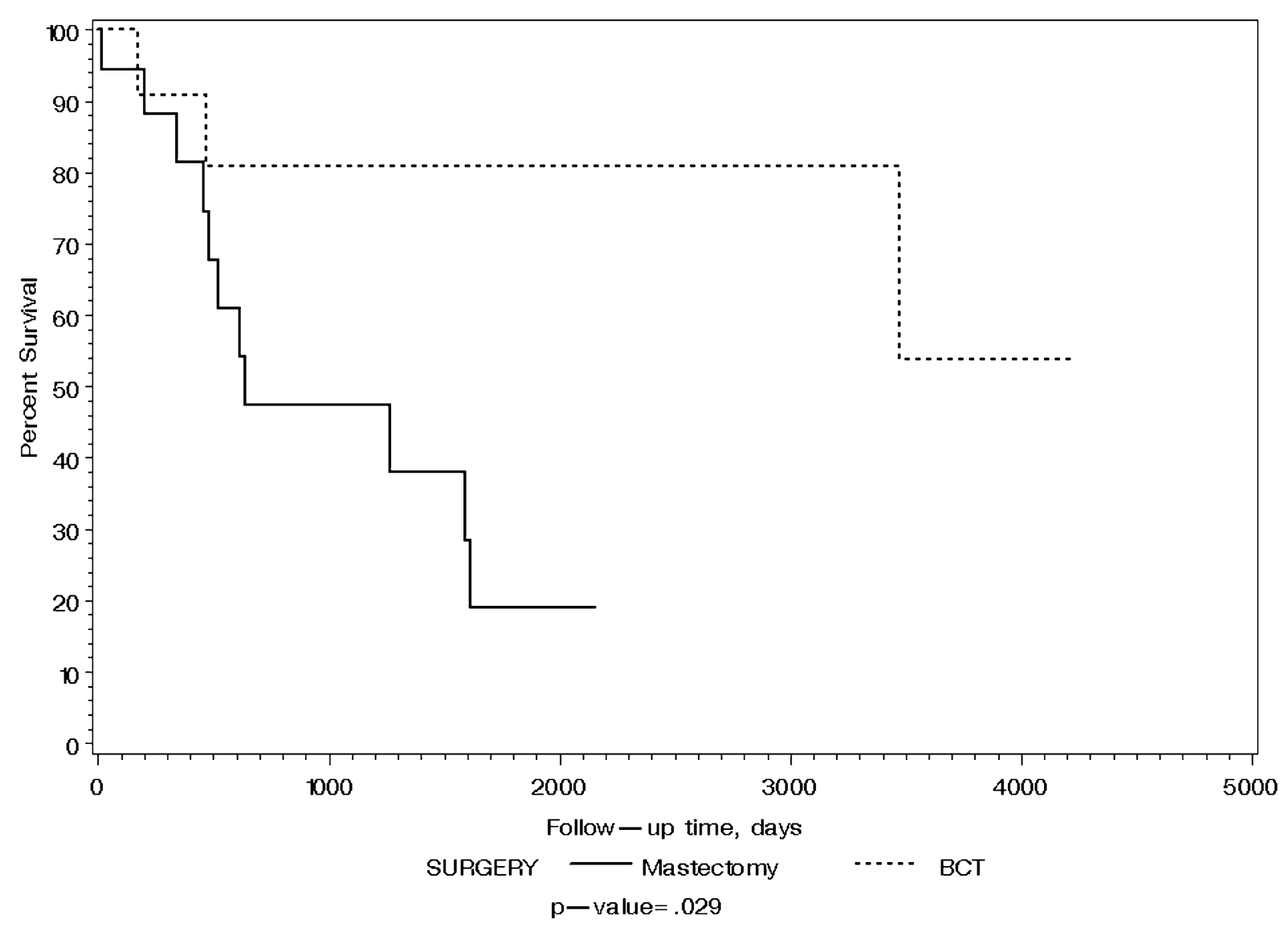

Figure 2 Survival of patients with BCT and mastectomy for treatment of MBC

\section{Correlation of Snail with other tumor characteristics and} survival

Snail expression (percentage of tumor cells staining) did not correlate with age, tumor size, grade, type of surgery (mastectomy vs. BCT), ALN status, hormone receptor and HER2 status, and type of treatment (hormonal therapy vs. chemotherapy vs. radiotherapy) (all p >0.10). Furthermore, it did not correlate with survival (Hazard Ratio $=1.02 ; 95 \%$ CI: 0.98, 1.06; $\mathrm{p}=0.45$ ).

\section{Discussion}

Our findings confirm findings from other studies reporting that the majority of $\mathrm{MBC}$ are high grade, hormone receptor negative and ALN negative. Despite presenting as node negative disease, the overall survival is low. We did not observe a significant difference with respect to overall survival between those who did and did not receive chemotherapy ( $\mathrm{p}=0.87$ by $\log$ rank test), although the sample size is small. Similarly, no difference was seen between those who did and did not get radiotherapy ( $\mathrm{p}=0.13$ by $\log$ rank test).

Table 3 Immunoexpression of the different markers in MBC, myofibroblastomas phyllodes tumor, and PASH

\begin{tabular}{lcccc}
\hline Antibody & MBC (\%) & Myofibroblastoma (\%) & Phyllodes Tumor (\%) & PASH (\%) \\
\hline SNAIL & $34 / 34(100 \%)$ & $4 / 4(100 \%)$ & $14 / 14(100 \%)$ & $7 / 8(87.5 \%)$ \\
EGFR & $34 / 34(100 \%)$ & $0 / 4(0 \%)$ & $13 / 14(92.9 \%)$ & $8 / 8(100 \%)$ \\
OSCAR & $29 / 34(85.3 \%)$ & $0 / 4(0 \%)$ & $2 / 14(14.3 \%)$ & $0 / 8(0 \%)$ \\
WS-KER & $26 / 34(76.5 \%)$ & $0 / 4(0 \%)$ & $0 / 14(0 \%)$ & $0 / 8(0 \%)$ \\
P63 & $23 / 34(56.7 \%)$ & $0 / 4(0 \%)$ & $0 / 14(0 \%)$ & $0 / 8(0 \%)$ \\
\hline
\end{tabular}

$\mathrm{MBC}=$ metaplastic breast carcinoma

PASH = pseudoangiomatous stromal hyperplasia 
Table 4 Sensitivity, Specificity, Positive (PPV) and Negative (NPV) Predictive Values of the different immunomarkers (\%)

\begin{tabular}{lllllll}
\hline Stains vs. Case & $\mathbf{N}$ & $\begin{array}{l}\text { Overall } \\
\text { Agreement, } \% \\
\mathbf{( 9 5 \% ~ C l )}\end{array}$ & Sensitivity, \% (95\% Cl) & Specificity, \% (95\% Cl) & PPV & NPV \\
\hline EGFR & 60 & $65.0(52.4,75.8)$ & $100.0(89.9,100.0)$ & $19.2(8.5,37.9)$ & 61.8 & 100.0 \\
\hline OSCAR & 60 & $88.3(77.8,94.2)$ & $85.3(69.9,93.6)$ & $92.3(75.9,97.9)$ & 93.6 & 82.8 \\
\hline P63 & 60 & $81.7(70.1,89.4)$ & $67.6(50.8,80.9)$ & $100.0(87.1,100.0)$ & 100.0 & 70.3 \\
\hline SNAIL & 60 & $58.3(45.7,71.8)$ & $100.0(89.9,100.0)$ & $3.8(0.7,18.9)$ & 57.6 & 100.0 \\
\hline WSKER & 60 & $86.7(75.8,93.1)$ & $76.5(60.0,87.6)$ & $100.0(87.1,100.0)$ & 100.0 & 76.5 \\
\hline OSCAR \& P63 \& WSKER & 60 & $90.0(79.9,95.3)$ & $88.2(73.4,95.3)$ & $92.3(75.9 .97 .9)$ & 93.8 & 85.7 \\
\hline OSCAR \& WSKER & 60 & $88.3(77.8,94.2)$ & $85.3(69.9,93.5)$ & $92.3(75.9,97.9)$ & 93.6 & 82.8 \\
\hline OSCAR \& P63 & 60 & $90.0(79.9,95.3)$ & $88.2(73.4,95.3)$ & $92.3(75.9 .97 .9)$ & 93.8 & 85.7 \\
\hline P63 \& WSKER & 60 & $90.0(79.9,95.3)$ & $82.4(66.5,91.7)$ & $100.0(87.1,100.0)$ & 100.0 & 81.2 \\
\hline
\end{tabular}

EGFR = epidermal growth factor receptor; WS-KER = wide spectrum keratin

In one study, no differences were found in Snail expression as related to ductal or lobular cancer subtypes, tumor grade, or luminal versus basal array profile [8], but metaplastic carcinomas were not included in the analyses. In another study, Blanco et al. [20] did not find differences in Snail expression related to histologic type, lymph node disease and high-moderate tumor grade [20]. Similarly, we did not find any significant association between Snail expression and other clinicopathologic factors (age, tumor size, grade, type of surgery, ALN status, hormone receptor and HER2 status, and type of treatment).

Breast conservation appears to be a reasonable treatment option with better survival than mastectomy. Although most MBC are high grade, there are a few variants that are low grade and behave indolently, such as low grade adenosquamous [21] and fibromatosis-like spindle cell carcinoma [22,23]. Several investigators suggest that those variants of $\mathrm{MBC}$ can be treated with BCT if the tumor size allows [21,22]. Dave et al. [24] have found that breast conservation to be a reasonable treatment option with equivalent survival to mastectomy, and adjuvant radiation is essential for achieving high local control rates after conservative surgery [24]. Matrix-producing carcinoma and biphasic metaplastic sarcomatoid carcinoma (carcinosarcoma) are aggressive subtypes of $\mathrm{MBC}$ with a worse clinical outcome than conventional invasive ductal carcinoma (IDC) with a decreased locoregional recurrence-free survival $(\mathrm{p}=$ 0.001 ) and decreased distant recurrence-free survival $(\mathrm{p}=0.001)[25]$. Several investigators are suggesting modified radical mastectomy with adjuvant treatment (radiation and/or chemotherapy) for patients with aggressive subtypes of $\mathrm{MBC}$, particularly for patients with T2 and higher stage disease [25,26]. Dave et al. [24] have shown BCT is equivalent to mastectomy in terms of survival. In our study, we found patients treated with $\mathrm{BCT}$ to have significantly better survival than those treated with mastectomy. Those patients treated with $\mathrm{BCT}$ presented with smaller tumor size and, generally, better tumor grade, indicating they may have had less severe disease.

Unlike our study and others [24,27], Khan et al. [28] and Sayed at al [29], have found higher rates of axillary lymph node involvement (40\% and 53\% respectively), and therefore proposed axillary lymph node staging. Furthermore, several investigators found that positive axillary nodes at presentation are strongly associated with worse survival $[24,30]$. In our study, only 4 of 13 (30.8\%) patients have axillary lymph node involvement at presentation, although 21 did not have axillary nodes assessed.

Overall, MBC has a worse disease-free survival, and a significantly decreased overall survival, when compared to typical conventional breast carcinoma $[1,28,29]$. However, Gibson et al. [31] have found that survival in MBC appears to be similar to that of conventional ductal adenocarcinoma, when stratified by stage [31]. Furthermore, they did not find adjuvant chemotherapy to be of benefit, by multivariate analysis [31]. Using multivariate analysis, they also did not find an impact on recurrence or survival with regard to tumor size, age, menopausal status, nodal status, histologic subtype, adjuvant therapy, or extent of surgery [31]. In our study, we also found no difference in survival associated with age, tumor size, grade, ALN status, hormone receptor and HER2 status, or type of treatment, likely due to the small sample size providing limited statistical power.

MBC usually develop hematogenous metastases (lung and bone), in keeping with the sarcomatous phenotype $[29,32]$. Usually, MBC tends to be estrogen and progesterone receptor negative [28,29]. Metaplastic carcinomas are thought to be of basal-cell phenotype based on immunohistochemical profile [33], and therefore most 


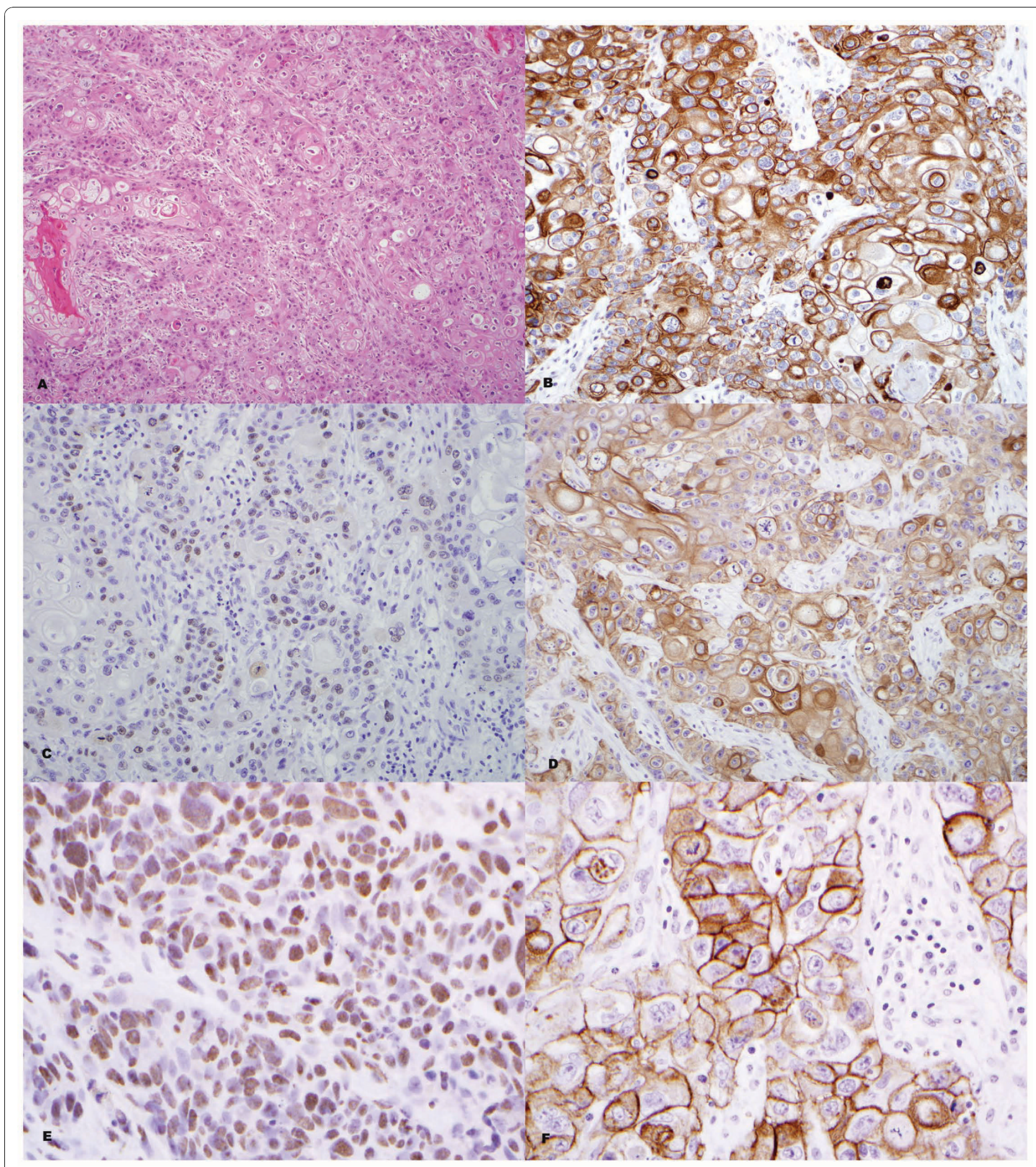

Figure 3 High grade squamous cell carcinoma (A; H\&E - 40X) with positive staining for OSCAR (B; 40x), p63 (C; 40X), WS-KER (D; 40X), SNAIL (E; 60x) and EGFR (F; 60x). 


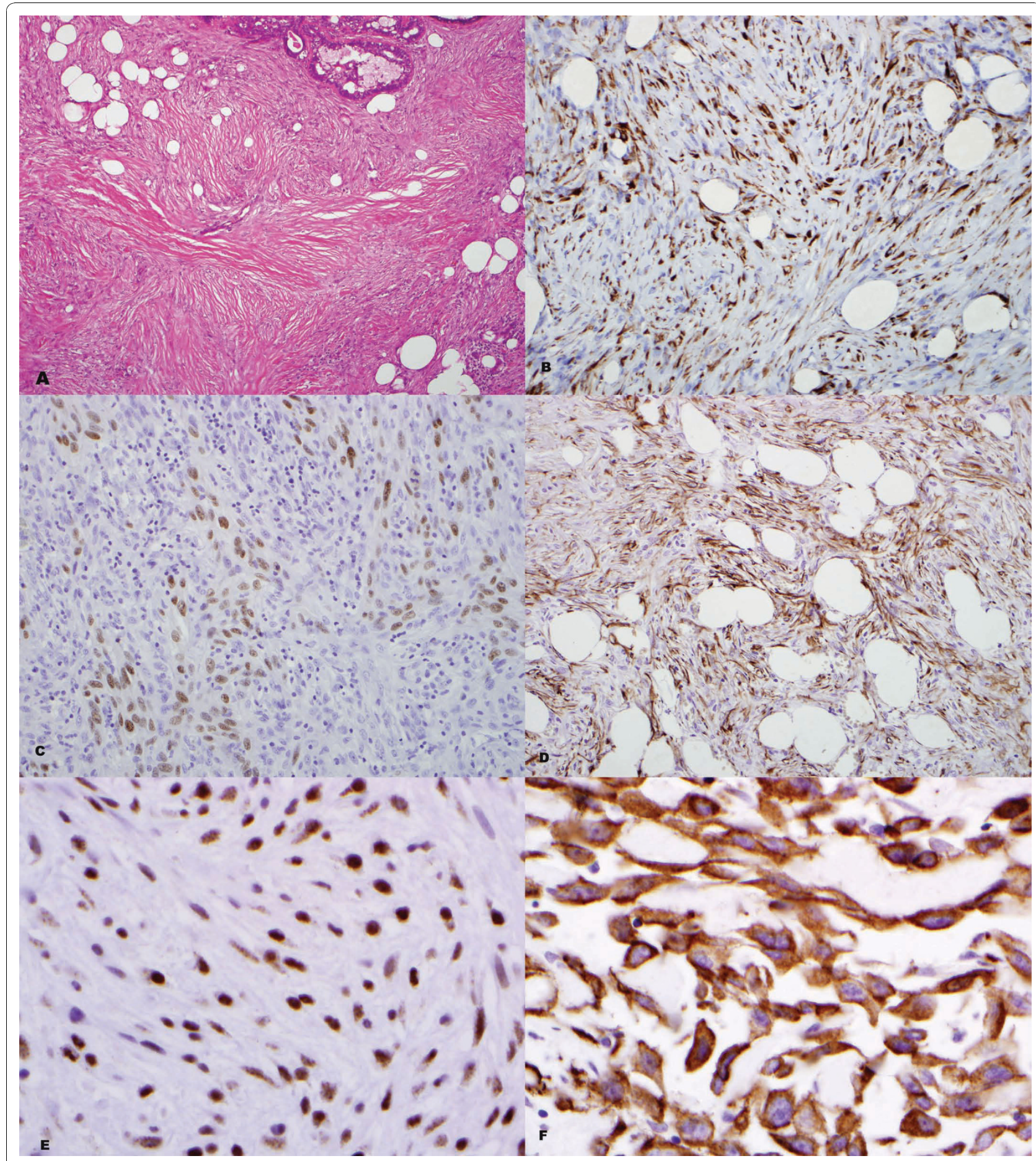

Figure 4 High grade spindle carcinoma (A; H\&E - 40x) with positive staining for OSCAR (B; 40X), p63 (C; 40x), WS-KER (D; 40X), SNAIL (E; 60X) and EGFR (F; 60X). 
likely will express basal keratins (CK5/6, CK14) [15]. A subset of MBC (specifically adenosquamous carcinoma) arises in association with papillomas or complex sclerosing lesions [34,35].

Since MBC mimic other spindle cell lesions of the breast, immunohistochemistry, specifically the use of cytokeratins, are valuable in differentiating between the two entities [22,23,27,36]. Carter et al. [27] found that pankeratin (MNF116) is the most sensitive marker (93\%), followed by cytokeratins 14 (90\%) for identifying $\mathrm{MBC}$. Other markers that are positive in $\mathrm{MBC}$ but to a lesser extent include CAM 5.2 (40\%) and AE1/3 (41\%) [27]. Several recent studies have described that some metaplastic carcinomas exhibit myoepithelial differentiation. Dunne et al. [15] reported at least focal staining for smooth muscle actin (SMA) in 79\% (11/14) of MBC. In addition, they noted frequent expression of the basal cell and myoepithelial keratins $34 \beta E 12$, CK5 and CK14 [15]. Reis-Filho et al. [37] also found frequent positivity for SMA and CK14, as well as immunoreactivity for S100 protein, p63, and the novel myoepithelial markers, maspin and p-cadherin. Other investigators have identified consistent expression of maspin and cadherins in sarcomatoid breast carcinoma [38]. Koker and Kleer [39] reported expression of p63 in all 10 spindle cell carcinomas examined, compared with 1 of 174 ( $0.6 \%)$ of nonmetaplastic breast carcinomas and 0 of 10 phyllodes tumors. In a study of 20 spindle cell metaplastic carcinomas, Leible et al. [40] found positive staining for p63 (70\%), SMA (60\%), S100 protein (45\%) and CD10 (80\%), in addition to frequent immunoreactivity for maspin, CD29, and 14-3 $\sigma$ (markers that appear to be preferentially expressed in myoepithelial cells). Tse et al. [41] found p63 to be a useful marker in the diagnosis of MBC with a sensitivity of $65 \%$, specificity of $96 \%$, a PPV and NPV of $96 \%$ and $66 \%$, respectively, and an accuracy of $78 \%$. In our study, we have found that OSCAR, WSKER and p63 to be the most sensitive and specific markers for identifying MBC.

Although EGFR is expressed in MBC (66\%), no EGFR or KIT activating mutations are present [33]. $\alpha \mathrm{B}$-crystallin is another novel marker found to be highly expressed in MBC (86\%) [42]. The present study is the first to evaluate Snail as a possible marker for diagnosis of MBC. Although Snail is a sensitive marker (100\%), it has a low specificity (3.8\%) because it is expressed promiscuously in other spindle cells lesions of the breast.

\section{Conclusions}

Snail is neither a good diagnostic nor a prognostic marker for MBC. MBC tend to be high grade, triple-negative (negative for estrogen and progesterone receptors and HER2) carcinomas with few axillary lymph node metastases and reduced overall survival. Our findings support the diagnostic utility of p63, OSCAR and WS-KER as a panel in the diagnosis of MBC and in the differentiation of these tumors from other spindle cell lesions of the breast.

\section{Abbreviations}

EGFR: epidermal growth factor; MBC: metaplastic breast carcinoma; WS-KER: wide spectrum cytokeratin;

\section{Author details}

'Department of Laboratory Medicine and Pathology, Mayo Clinic, Rochester, MN, USA. ${ }^{2}$ The Breast and Oncology Center, St. Mary's Health System, Southbury, CT, USA. ${ }^{3}$ Department of Medical Oncology, Clínica Universidad de Navarra, Spain. ${ }^{4}$ Department of Health Sciences Research, Mayo Clinic, Rochester, MN, USA. ${ }^{5}$ Department of Surgery, Mayo Clinic, Rochester, MN, USA. ${ }^{6}$ Department of Pathology, Henry Ford Hospital, Detroit, MI, USA.

\section{Authors' contributions}

AN: Concept and design of the study, data collection, data analysis and interpretation, writing of final draft and review of revised manuscript draft. NS: Data collection and analysis, revision and approval of final and revised manuscript draft. MS: Data analysis and interpretation, revision and approval of final and revised manuscript draft. SCB: Participated in the design of the study, performed statistical analysis and interpretation of data, revision and approval of final and revised manuscript draft. JCB: Critique and revision of final and revised manuscript draft. TC: Critique and revision of final and revised manuscript draft. AD: Critique and revision of final and revised manuscript draft. All authors read and approved the final and revised manuscript.

\section{Competing interests}

The authors declare that they have no competing interests.

Received: 16 September 2010 Accepted: 26 November 2010 Published: 26 November 2010

\section{References}

1. Luini A, Aguilar M, Gatti G, Fasani R, Botteri E, Brito JA, Maisonneuve P, Vento AR, Viale G: Metaplastic carcinoma of the breast, an unusual disease with worse prognosis: the experience of the European Institute of Oncology and review of the literature. Breast Cancer Res Treat 2007, 101:349-353.

2. Günhan-Bilgen I, Memis A, Ustun EE, Zekioglu O, Ozdemir N: Metaplastic carcinoma of the breast: clinical, mammographic, and sonographic findings with histopathologic correlation. AJR 2002, 178:1421-1425.

3. Park JM, Han BK, Moon WK, Choe YH, Ahn SH, Gong G: Metaplastic carcinoma of the breast: mammographic and sonographic findings. J Clin Ultrasound 2000, 28:179-186.

4. Lien HC, Hsiao YH, Lin YS, Yao YT, Juan HF, Kuo WH, Hung MC, Chang KJ, Hsieh FJ: Molecular signatures of metaplastic carcinoma of the breast by large-scale transcriptional profiling: identification of genes potentially related to epithelial-mesenchymal transition. Oncogene 2007, 26(57):7859-71.

5. Knutson KL, Lu H, Stone B, Reiman JM, Behrens MD, Prosperi CM, Gad EA, Smorlesi A, Disis ML: Immunoediting of cancers may lead to epithelial to mesenchymal transition. J Immunol 2006, 177(3):1526-33.

6. Mani SA, Guo W, Liao MJ, Eaton EN, Ayyanan A, Zhou AY, Brooks M, Reinhard F, Zhang CC, Shipitsin M, Campbell LL, Polyak K, Brishen C, Yang J, Weinberg RA: The epithelial-mesenchymal transition generates cells with properties of stem cells. Cell 2008, 133(4):704-15.

7. Santisteban M, Reiman JM, Asiedu MK, Behrens MD, Nassar A, Kalli KR, Haluska P, Ingle JN, Hartmann LC, Manjili MH, Radisky DC, Ferrone S, Knutson KL: Immune-induced epithelial to mesenchymal transition in vivo generates breast cancer stem cells. Cancer Res 2009, 69(7):2887-95.

8. Moody SE, Perez D, Pan TC, Sarkisian CJ, Portocarrero CP, Sterner CJ, Notorfrancesco KL, Cardiff RD, Chodosh LA: The transcriptional repressor Snail promotes mammary tumor recurrence. Cancer Cell 2005, 8(3):197-209. 
9. Cano A, Perez-Moreno MA, Rodrigo I, Locascio A, Blanco MJ, del Barrio MG, Portillo F, Nieto MA: The transcription factor Snail controls epithelialmesenchymal transitions by repressing E-cadherin expression. Nat Cell Biol 2000, 2(2):76-83.

10. Zhou BP, Hung MC: Wnt, hedgehog and Snail: sister pathways that control by GSK-3beta and beta-Trcp in the regulation of metastasis. Cell Cycle 2005, 4(6):772-6.

11. Sorlie T, Perou CM, Tibshirani R, Aas T, Geisler S, Johnsen H, Akslen LA, Fluge O, Pergamenschikov A, Williams C, Zhu SX, Lǿnning PE, BǿrresenDale AL, Brown PO, Botstein D: Gene expression patterns of breast carcinomas distinguish tumor subclasses with clinical implications. Proc Natl Acad Sci USA 2001, 98(19):10869-74.

12. van't Veer LJ, Paik S, Hayes DF: Gene expression profiling of breast cancer: a new tumor marker. J Clin Oncol 2005, 23(8):1631-5.

13. Wang Y, Klijn JG, Zhang Y, Sieuwerts AM, Look MP, Yang F, Talantov D, Timmermans M, Meijer-van Gelder ME, Yu J, Jutkoe T, Berns EM, Atkins D, Foekens JA: Gene-expression profiles to predict distant metastasis of lymph-node-negative primary breast cancer. Lancet 2005 365(9460):671-9.

14. Fujita N, Jaye DL, Kajita M, Geigerman C, Moreno CS, Wade PA: MTA3, a Mi-2/NuRD complex subunit, regulates an invasive growth pathway in breast cancer. Cell 2003, 113(2):207-19.

15. Dunne B, Lee AH, Pinder SE, Bell JA, Ellis IO: An immunohistochemical study of metaplastic spindle cell carcinoma, phyllodes tumor and fibromatosis of the breast. Hum Pathol 2003, 34:1009-1015.

16. Wargotz ES, Deos PH, Norris HJ: Metaplastic carcinomas of the breast. II. Spindle cell carcinoma. Hum Pathol 1989, 20:732-740.

17. Wargotz ES, Norris HJ: Metaplastic carcinomas of the breast. I. Matrixproducing carcinoma. Hum Pathol 1989, 20:628-635.

18. Wargotz ES, Norris HJ: Metaplastic carcinomas of the breast. III. Carcinosarcoma. Cancer 1989, 64:1490-1499.

19. Wargotz ES, Norris HJ: Metaplastic carcinomas of the breast. IV. Squamous cell carcinoma of ductal origin. Cancer 1990, 65:272-276.

20. Blanco MJ, Moreno-Bueno G, Sarrio D, Locascio A, Cano A, Palacios J, Nieto MA: Correlation of Snail expression with histological grade and lymph node status in breast carcinomas. Oncogene 2002, 21(20):3241-6.

21. Rosen PP, Ernsberger D: Low-grade adenosquamous carcinoma. A variant of metaplastic mammary carcinoma. Am J Surg Pathol 1987, 11:351-358.

22. Sneige N, Yaziji H, Mandavilli SR, Perez ER, Ordonez NG, Gown AM, Ayala A: Low-grade (fibromatosis-like) spindle cell carcinoma of the breast. Am J of Surg Pathol 2001, 25:1009-1016.

23. Brogi E: Benign and malignant spindle cell lesions of the breast. Semin Diagn Pathol 2004, 21:57-64.

24. Dave G, Cosmatos H, Do T, Lodin K, Varshney D: Metaplastic carcinoma of the breast: a retrospective review. Int J Radiat Oncol Biol Phys 2006, 64:771-775.

25. Downs-Kelly E, Nayeemuddin KM, Albarracin C, Wu Y, Hunt KK, Gilcrease MZ: Matrix-producing Carcinoma of the Breast: An Aggressive Subtype of Metaplastic Carcinoma. Am J Surg Pathol 2009, 33(4):534-41.

26. Hennessy BT, Giordano S, Broglio K, Duan Z, Trent J, Buchholz TA, Babiera G, Hortobagyi GN, Valero V: Biphasic metaplastic sarcomatoid carcinoma of the breast. Ann Oncol 2006, 17:605-613.

27. Carter MR, Hornick JL, Lester S, Fletcher CD: Spindle cell (sarcomatoid) carcinoma of the breast: a clinicopathologic and immunohistochemical analysis of 29 cases. Am J Surg Pathol 2006, 30:300-309.

28. Khan HN, Wyld L, Dunne B, Lee AH, Pinder SE, Evans AJ, Robertson JF: Spindle cell carcinoma of the breast: a case series of a rare histological subtype. Eur J Surg Oncol 2003, 29:600-603.

29. Al Sayed AD, El Weshi AN, Tulbah AM, Rahal MM, Ezzat AA: Metaplastic carcinoma of the breast clinical presentation, treatment results and prognostic factors. Acta Oncol (Stockholm, Sweden) 2006, 45:188-195.

30. Chao TC, Wang CS, Chen SC, Chen MF: Metaplastic carcinomas of the breast. J Surg Oncol 1999, 71:220-225

31. Gibson GR, Qian D, Ku JK, Lai LL: Metaplastic breast cancer: clinical features and outcomes. Am Surg 2005, 71:725-730.

32. Kurian KM, Al-Nafussi A: Sarcomatoid/metaplastic carcinoma of the breast: a clinicopathological study of 12 cases. Histopathology 2002, 40:58-64.

33. Gilbert JA, Goetz MP, Reynolds CA, Ingle JN, Giordano KF, Suman VJ, Blair HE, Jenkins RB, Lingle WL, Reinholz MM, Adjei AA, Ames MM: Molecular analysis of metaplastic breast carcinoma: high EGFR copy number via aneusomy. Mol Cancer Ther 2008, 7:944-951.
34. Gobbi H, Simpson JF, Jensen RA, Olson SJ, Page DL: Metaplastic spindle cell breast tumors arising within papillomas, complex sclerosing lesions, and nipple adenomas. Mod Pathol 2003, 16:893-901.

35. Denley H, Pinder SE, Tan PH, Sim CS, Brown R, Barker T, Gearty J, Elston CW, Ellis IO: Metaplastic carcinoma of the breast arising within complex sclerosing lesion: a report of five cases. Histopathology 2000, 36:203-209.

36. Tse GM, Tan PH, Lui PC, Putti TC: Spindle cell lesions of the breast-the pathologic differential diagnosis. Breast Cancer Res Treat 2008, 109:199-207.

37. Reis-Filho JS, Milanezi F, Paredes J, Silva P, Pereira EM, Maeda SA, de Carvalho LV, Schmitt FC: Novel and Classic Myoepithelial/Stem Cell Markers in Metaplastic Carcinomas of the Breast. Appl Immunohistochem Mol Morphol 2003, 11:1-8.

38. Popnikolov NK, Ayala AG, Graves K, Gatalica Z: Benign Myoepithelial Tumors of the Breast Have Immunophenotype Characteristics Similar to Metaplastic Matrix Producing and Spindle Cell Carcinomas. Am J Clin Pathol 2003, 120:161-167.

39. Koker MM, Kleer CG: P63 expression in Breast Cancer. A Highly Sensitive and Specific Marker of Metaplastic Carcinoma. Am J Surg Pathol 2004, 28:1506-15122.

40. Leibl S, Sommersacher A, Denk H, Moinfar F: Metaplastic Breast Carcinomas: Are they of Myoepithelial Differentiation? Immunohistochemical Profile of the Sarcomatoid Subtype Using Novel Myoepithelial Markers. Am J Surg Pathol 2005, 29:347-353.

41. Tse GM, Tan PH, Chaiwun B, Putti TC, Lui PC, Tsang AK, Wong FC, Lo AW: p63 is useful in the diagnosis of mammary metaplastic carcinomas. Pathology 2006, 38:16-20.

42. Sitterding SM, Wiseman WR, Schiller CL, Luan C, Chen F, Moyano JV, Watkin WG, Wiley EL, Cryns VL, Diaz LK: Alpha B-crystallin: a novel marker of invasive basal-like and metaplastic breast carcinomas. Ann Diagn Pathol 2008, 12:33-40.

doi:10.1186/1746-1596-5-76

Cite this article as: Nassar et al:: Diagnostic utility of snail in metaplastic breast carcinoma. Diagnostic Pathology 2010 5:76.

\section{Submit your next manuscript to BioMed Central and take full advantage of:}

- Convenient online submission

- Thorough peer review

- No space constraints or color figure charges

- Immediate publication on acceptance

- Inclusion in PubMed, CAS, Scopus and Google Scholar

- Research which is freely available for redistribution

Submit your manuscript at www.biomedcentral.com/submit
C Biomed Central 